J. Perinat. Med. 3 (1975) 276

\section{Maternal and fetal plasma levels of free corticosteroids in pathological deliveries}

\author{
J. Schmid
}

Department of Gynecology and Obstetrics, University of Zurich, Switzerland (Chairman: Prof. Dr. W. E. SCHREINER)

Received February 18, 1975. Accepted October 10, 1975.
The corticosteroid level in umbilical blood shows large variations. Several factors affect this level: gestational age $[13,18,19]$, type of delivery $[5,10,19,20]$ and the stress of delivery $[3,8,13]$. It is not certain; how far data obtained in animal experiments $[2,4,9]$ can be applied to man. We do not know whether human delivery is also preceded by a rise in the fetal corticosteroid level as suggested by some $[13,14]$ or whether this rise is only a response of the fetal adrenal to intrauterine stress [16].

The concentration of free corticosteroids and the $\mathrm{pH}$ were determined during pathological deliveries to asses the effect of the fetal adrenal gland. Normal deliveries were used to obtain control values.

\section{Material and method}

We examined 41 mothers and their infants. A pathological delivery was diagnosed from the following criteria:

1. acidosis as determined from the $\mathrm{pH}$

2. and/or an obstetric disease of mother or child.

Fetal blood was collected from the hyperemic fetal head skin according to SALING during delivery, and from the umbilical artery and vein between two ligatures, after birth. Maternal blood was taken from the cubital vein. In all 41 cases blood could be collected during delivery. In vaginal deliveries some could also be collected during the dilation and expulsion periods. Delivery was divided into the following stages:
EP $1=$ early dilation period (cervix dilated $1-5 \mathrm{~cm}$ )

EP 2 = late dilation period (cervix dilated 6 to $10 \mathrm{~cm}$ )

$\mathrm{AP}=$ expulsion period (cervix fully dilated, head entering pelvis)

$\mathrm{NA} / \mathrm{NV}=$ point of time of delivery: values of umbilical artery and vein.

The $\mathrm{pH}$ and free corticosteroids were determined in the blood; the latter according to MURPHY [12] using the competitive protein binding assay. The reliability of this method is $\pm 8.6 \mu \mathrm{g} /$ $100 \mathrm{ml}$ with a probability error of less than $5 \%$ [17]. We examined 24 non-induced spontaneous vaginal deliveries, 8 forceps and 9 caesarean sections. Seven of the vaginal deliveries were premature, the gestational age of the infants being 31 to 37 weeks, 35 weeks on the average.

\section{Results}

Since the 41 cases had diverse pathologies and parameters were not equally distributed, there was no sense in obtaining mean values and standard deviations and to compare them with normal values. For the same reason the correlation coefficient between $\mathrm{pH}$ and corticosteroid levels was not calculated. Data are hence given graphically and individual values are shown in the tables as obtained at the moment of birth.

\subsection{Vaginal spontaneous deliveries}

Corticosteroids (CS) were determined at the time of birth in 24 pathological cases and in 


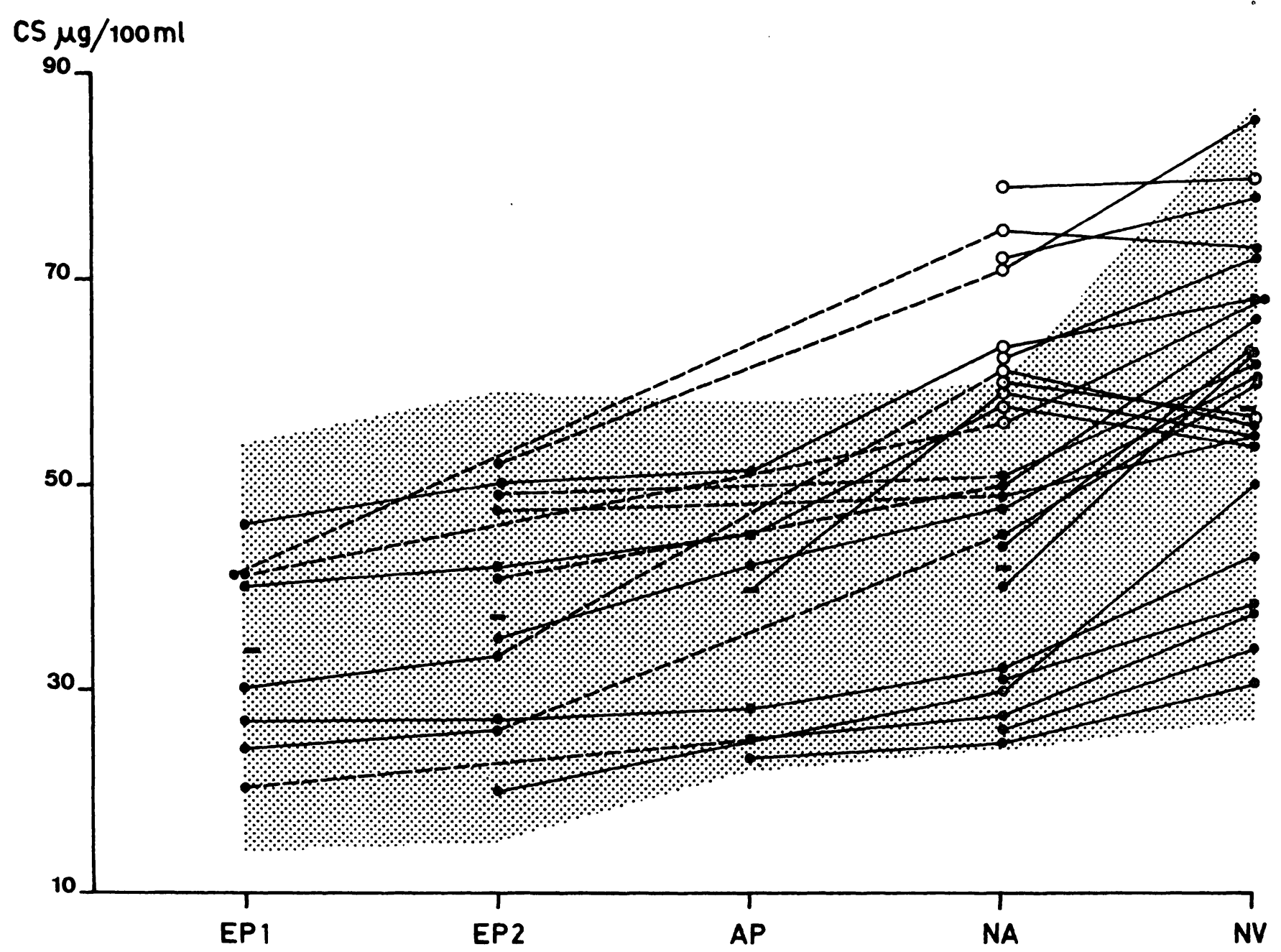

Fig. 1. Concentration of free corticosteroids (CS $\mu \mathrm{g} / 100 \mathrm{ml}$ ) in fetal plasma in 24 vaginal deliveries.

Pointed areas $=$ normal range with mean values (black line)

points $=$ actual $\mathrm{pH}$-values $>7.20 \quad$ circle $=$ actual $\mathrm{pH}$-values $<7.20$.

some also during delivery (Fig. 1). A continuous rise was found, as in normal deliveries and levels were the same as for normal births. If acidosis occurs the normal level is usually exceeded. Acidosis occurred during the last stage of labor. All deliveries were routinely controlled by microblood analyses during the last stages of labor.

Table I gives individual values at the time of delivery of $\mathrm{pH}$ and $\mathrm{CS}$ concentrations in maternal and umbilical plasma and also the arterio-venous difference in corticosteroid concentration. In the first eleven cases with a $\mathrm{pH}$ value below 7.2, the CS level was outside the normal range in 7 cases and within it in four. Values in the umbilical vein, however, are all normal. Only one mother had $97 \mu \mathrm{g} / 100 \mathrm{ml}$, which is just above the maternal norm.
In cases 12 to 18 with a $\mathrm{pH}$ above 7.2 in the umbilical artery, both fetal and maternal values were normal.

In premature deliveries, cases 19 to 24; with normal $\mathrm{pH}$, the $\mathrm{CS}$ levels were lower than in term babies. This, however, is not statistically significant. Case 9 shows that the CS level can also rise in acidosis in the premature. The $a-v$ difference of CS is usually decreased in acidosis; sometimes even to a negative value. The normal difference is $15 \pm 5 \mu \mathrm{g} / 100 \mathrm{ml}$.

\subsection{Delivery by forceps}

Forceps were used under general anesthesia with nitrous oxide and Fluothane. In 4 cases such delivery was indicated by fetal acidosis, in two by preacidosis and in 2 because of severe late deceleration with normal pH. In 5 of the 8 cases 
Tab. I. Values of $\mathrm{pH}$ and free corticosteroids (CS $\mu \mathrm{g} / 100 \mathrm{ml}$ ) in the umbilical artery (UA), vein (UV) and maternal vein and the $\mathrm{a}-\mathrm{v}$ difference. 24 spontaneous deliveries; $\mathrm{EPH}=\mathrm{EPH}$ gestosis; visible constriction with cord = VC; meconium $=\mathrm{Mec} ; \mathrm{T}+=$ postmature $\mathrm{PM}=$ premature.

\begin{tabular}{|c|c|c|c|c|c|c|c|c|}
\hline \multirow[t]{2}{*}{ case } & \multirow[t]{2}{*}{ diagnosis } & \multicolumn{2}{|c|}{ UA } & \multicolumn{2}{|c|}{ UV } & \multicolumn{2}{|c|}{ mother } & \multirow{2}{*}{$\begin{array}{c}\Delta C S \\
\mathrm{UA}-\mathrm{UV}\end{array}$} \\
\hline & & $\mathrm{pH}_{\mathrm{act}}$ & $\mathrm{CS}$ & $\mathrm{pH}_{\mathrm{act}}$ & CS & $\mathrm{pH}_{\mathrm{act}}$ & CS & \\
\hline 1 & $\mathrm{EPH}$ & 7.081 & 60 & 7.156 & 57 & 7.421 & 70 & -3 \\
\hline 2 & EPH & 7.090 & 79 & 7.188 & 80 & 7.345 & 86 & 1 \\
\hline 3 & $\mathrm{Mec}$ & 7.128 & 61 & 7.274 & 56 & 7.363 & 78 & -5 \\
\hline 4 & VC & 7.131 & 75 & 7.268 & 73 & 7.389 & 92 & -2 \\
\hline 5 & $\mathrm{EPH}$ & 7.159 & 58 & 7.314 & 54 & 7.424 & 68 & -4 \\
\hline 6 & $\mathrm{VC}$ & 7.161 & 56 & 7.398 & 68 & 7.471 & 83 & 12 \\
\hline 7 & $\mathrm{EPH}$ & 7.170 & 72 & 7.288 & 78 & 7.385 & 97 & 6 \\
\hline 8 & $\mathrm{Mec}$ & 7.180 & 62 & 7.307 & 72 & 7.389 & 85 & 10 \\
\hline 9 & $\mathrm{PM} / \mathrm{VC}$ & 7.181 & 59 & 7.232 & 55 & 7.455 & 75 & -4 \\
\hline 10 & $\mathrm{Mec}$ & 7.184 & 72 & 7.246 & 86 & 7.356 & 91 & 14 \\
\hline 11 & $\mathrm{Mec}$ & 7.198 & 63 & 7.307 & 68 & 7.395 & 84 & 5 \\
\hline 12 & $\mathrm{VC}$ & 7.215 & 51 & 7.279 & 62 & 7.387 & 78 & 11 \\
\hline 13 & $\mathrm{~T}+$ & 7.256 & 49 & 7.290 & 55 & 7.308 & 66 & 6 \\
\hline 14 & $\mathrm{~T}+$ & 7.258 & 32 & 7.280 & 43 & 7.496 & 52 & 11 \\
\hline 15 & VC/Mec & 7.259 & 45 & 7.341 & 60 & 7.431 & 70 & 15 \\
\hline 16 & $\mathrm{~T}+$ & 7.280 & 28 & 7.294 & 38 & 7.396 & 48 & 10 \\
\hline 17 & $\mathrm{~T}+$ & 7.294 & 40 & 7.347 & 63 & 7.398 & 77 & 23 \\
\hline 18 & $\mathrm{~T}+$ & 7.371 & 50 & 7.398 & 66 & 7.450 & 86 & 16 \\
\hline 19 & $\mathrm{PM} / \mathrm{EPH}$ & 7.278 & 44 & 7.314 & 63 & 7.376 & 66 & 19 \\
\hline 20 & $\mathrm{PM} / \mathrm{EPH}$ & 7.301 & 48 & 7.352 & 60 & 7.362 & 70 & 12 \\
\hline 21 & $\mathrm{PM} / \mathrm{Mec}$ & 7.320 & 31 & 7.335 & 36 & 7.412 & 50 & 5 \\
\hline 22 & $\mathrm{PM} / \mathrm{EPH}$ & 7.328 & 30 & 7.375 & 50 & 7.441 & 54 & 20 \\
\hline 23 & $\mathrm{PM} / \mathrm{EPH}$ & 7.332 & 26 & 7.394 & 34 & 7.436 & 50 & 8 \\
\hline 24 & $\mathrm{PM} / \mathrm{VC}$ & 7.345 & 25 & 7.442 & 31 & 7.592 & 45 & 6 \\
\hline $1-11$ & & & & & & & & \\
\hline $\begin{array}{l}\text { NA-pH }<7.20 \\
12-18\end{array}$ & mean & & 65 & & 68 & & 82 & 2.7 \\
\hline $\begin{array}{l}\mathrm{NA}-\mathrm{pH}>7.20 \\
19-24\end{array}$ & mean & & 42 & & 55 & & 67 & 13 \\
\hline PM & mean & & 34 & & 48 & & 56 & 11.7 \\
\hline
\end{tabular}

Tab. II. 8 deliveries by forceps (see legend in Tab. I).

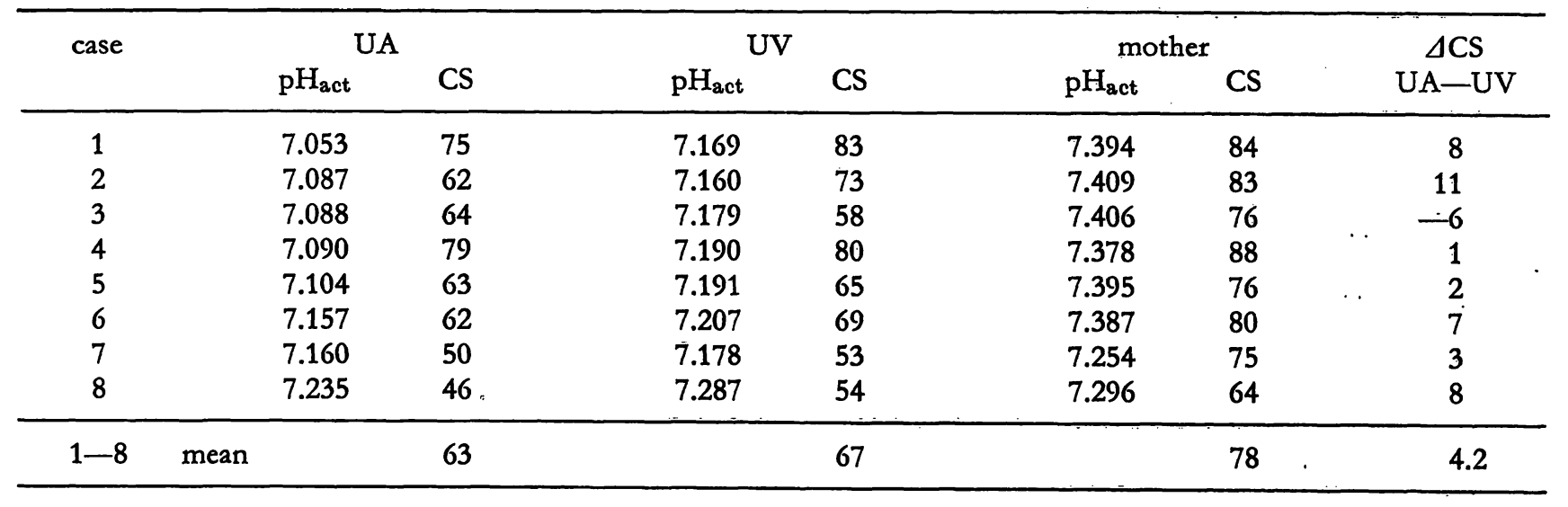




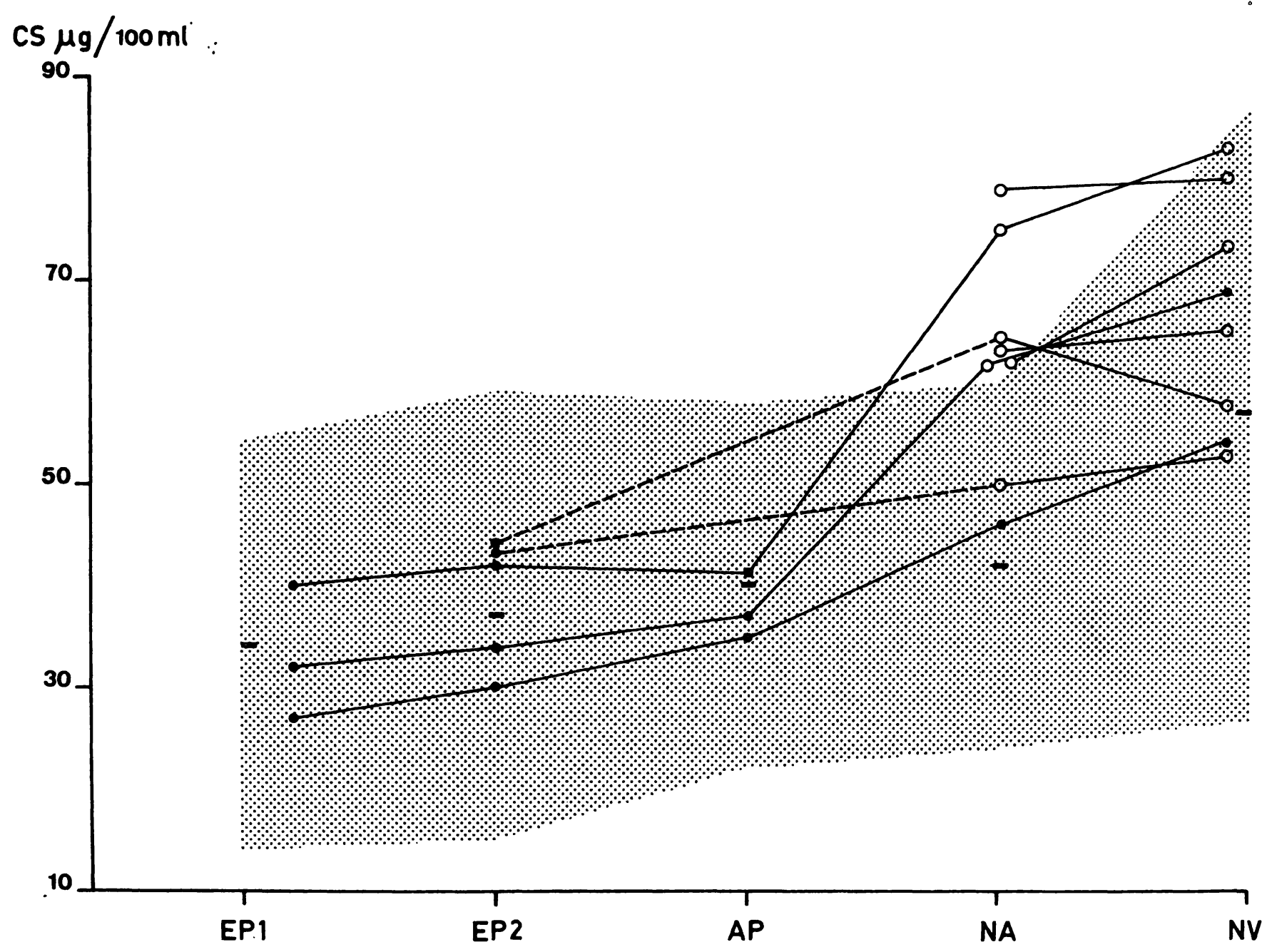

Fig. 2. Concentration of free corticosteroids $(\mathrm{CS} \mu \mathrm{g} / 100 \mathrm{ml})$ in fetal plasma in 8 deliveries by forceps (see legend of Fig. 1).

Tab. III: 9 cases of caesarean section (see legends in Tab. I).

\begin{tabular}{|c|c|c|c|c|c|c|c|c|c|}
\hline \multirow[b]{2}{*}{ Case } & \multirow[b]{2}{*}{ diagnosis } & \multirow{2}{*}{$\begin{array}{c}\text { Caesarian } \\
\text { section }\end{array}$} & \multicolumn{2}{|c|}{ UA } & \multicolumn{2}{|c|}{ UV } & \multicolumn{2}{|c|}{ mother } & \multirow{2}{*}{$\begin{array}{c}\Delta \mathrm{CS} \\
\mathrm{UA}-\mathrm{UV}\end{array}$} \\
\hline & & & $\mathrm{pH}_{\text {act }}$ & $\mathrm{CS}$ & $\mathrm{pH}_{\mathrm{act}}$ & CS & $\mathrm{pH}_{\mathrm{act}}$ & CS & \\
\hline 1 & Acidosis & secundary & 7.054 & 63 & 7.138 & 65 & 7.354 & $.80=$ & 2 \\
\hline 2 & Acidosis & secundary & 7.100 & 63 & 7.180 & 63 & 7.370 & 72 & 0 \\
\hline 3 & $\mathrm{~T}+/ \mathrm{Mec}$ & primary & 7.213 & 47 & 7.247 & 52 & 7.374 & 60 & 5 \\
\hline \multirow[t]{2}{*}{4} & induction & & & & & & & & \\
\hline & of labor & secundary & 7.222 & 45 & 7.297 & 63 & 7.341 & 80 & 18 \\
\hline \multirow[t]{2}{*}{5} & EPH/Pre- & & & & & & & & \\
\hline & acidosis & secundary & 7.223 & 59 & 7.281 & 68 & 7.470 & 83 & 9 \\
\hline 6 & Pre-acidosis & secundary & 7.245 & 36 & 7.309 & 42 & 7.384 & 47 & 6 \\
\hline 7 & small-for-date & primary & 7.250 & 61 & 7.293 & 88 & 7.395 & 97 & 27 \\
\hline \multirow[t]{2}{*}{8} & Breech pres. & & & & & & & & \\
\hline & $\mathrm{EPH}$ & primary & 7.297 & 53 & 7.288 & 72 & 7.365 & 83 & 19 \\
\hline \multirow[t]{2}{*}{9} & Mec/late & & & & & & & & \\
\hline & decelerations & secundary & 7.317 & 40 & 7.369 & 53 & 7.392 & 67 & 13 \\
\hline $1+2$ & mean & & & 63 & & 64 & & 76 & 1 \\
\hline $3-9$ & mean & & & 48 & & 62 & & 74 & 14 \\
\hline
\end{tabular}




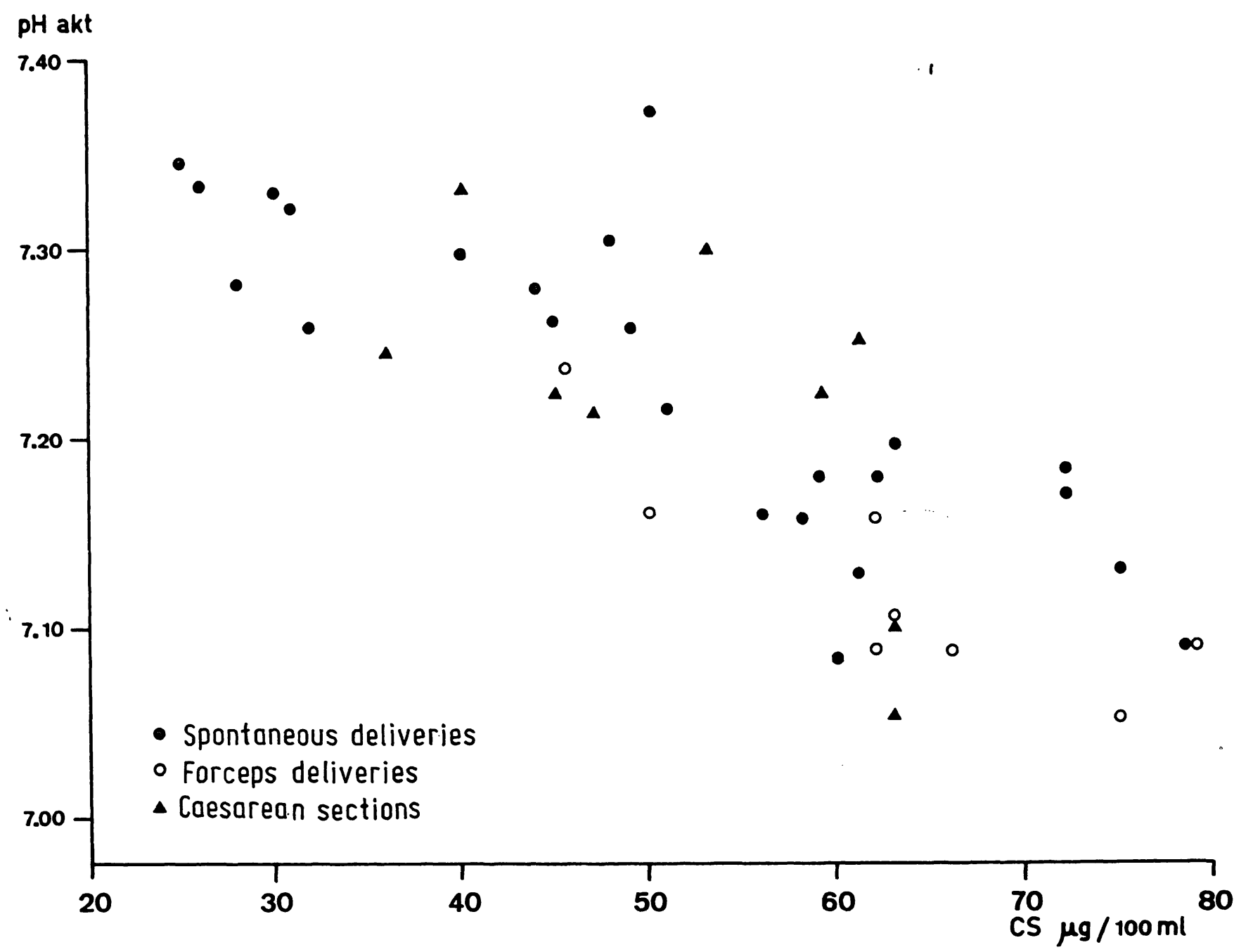

Fig. 3. Concentration of free corticosteroids in the plasma of umbilical artery in relation to the actual pH-value.

CS levels were also determined during labor (Fig. 2). Except for one case; CS values were outside the normal range in acidosis.

Values in the umbilical vein were in the upper normal range and they were normal in the maternal artery (Tab. II). The mean $a-\nabla$ CS difference is lower than normal.

\subsection{Caesarean section}

In 9 cases only blood collected at delivery could be analyzed (Tab. III). In 3 cases section was commenced before the initiation of labor. Data from cases 3 and 8 do not differ from those obtained in spontaneous deliveries. In case 7 the CS concentration in both mother and fetus are outside the normal values; even though there is no acidosis present. In 6 patients sections were performed in the last stage of labor. In two cases in whom acidosis in the umbilical artery could be found, the CS concentration was outside the normal range. The $\mathrm{a}-\mathrm{v}$ difference was $0 \mu \mathrm{g} / 100 \mathrm{ml}$ in one and $2 \mu \mathrm{g} / 100 \mathrm{ml}$ in the other case. If the $\mathrm{pH}$ is above $7.2 \mathrm{CS}$ levels are the same as in normal deliveries.

Fig. 3 shows the relationship between the $\mathrm{pH}$ and the CS blood level in the umbilical artery for all 41 cases. There is an inverse relation. This trend is independent of the type of delivery.

\section{Discussion}

The level of free CS rises in maternal and umbilical plasma with increasing gestational age $[11,13,18]$. A further rise is seen during labor and delivery [15]. We showed that this rise also occurs in fetal blood from the head [17]. At the end of delivery we found a mean of $42 \mu \mathrm{g} /$ 
$100 \mathrm{ml}$ stcroids with transcortin affinity in the umbilical artery. This is much lower than reported by KraURR [8]. Since progesterone is also detcrmined by our technique; we have higher values than Smith and Shrarman [18]. The progesterone level remains unchanged during labor $[7,15]$ and hence we conclude that the risc is duc to CS. The CS concentration in maternal and fetal blood also depends on the type of delivery. Values are higher after vaginal delivery than after cesarean sections commenced before the intiation of labor $[8,13,16,19]$. However, if sections were started after labor had commenced, differences were minimal [19]. The highest values were found after the use of forceps [8]. 'These differences were found for both total steroids $[8,19]$ and individual adrenal corticostcroids $[3,5,10,13,20]$. These data were thought to indicate an active role of the fetal adrenal cortex in the initiation of labor $[13,14$, 18]. The risc in fetal CS shown in animals has not been demonstrated in man. Perhaps it represents, depending on the type of delivery, a fetal response to the stress of delivery $[16,20]$.

Adrenocorticosteroids are differently distributed in fetal and maternal blood. In adults cortisol is quantitatively the most important. In fetal blood there is an equal amount or more cortisone [3, $13,20]$ and also more corticosterone [6]. MuRPHY et al. [13] found 3 times as much cortisol in the umbilical artery as in the umbilical vein; while no difference was found by others [3]. Stcroid metabolism in the fetus differs from that of the adult mainly because of increased or decreased en\%yme activitics [21].

These feto-maternal differences and the difficulty in determining the origin of fetal corticosteroids (maternal, placental, fetal) madc it appear rensonable to determine total corticosteroid concentrations; c. g. during fetal hypoxia. A rise in the AC'TH and a smaller one in the CS concentration in fetal sheep blood could be demonstrated during hypoxia [1].

We found a mean concentration of CS above the normal range in the umbilical artery in the presence of fetal acidosis. A fall in the $a-v$ difference was noted at the same time. These changes depend on the fetal $\mathrm{pH}$ and not on the mode of delivery. In cases of fetal acidosis after spontaneous deliveries a smaller rise in CS levels was found in the umbilical vein and maternal plasma. No differences were seen between caesarean and forceps deliveries. Thus we may conclude that the fetal adrenal gland sccretes more corticosteroids if intrauterine acidosis occurs.

Our results confirm those of others $[13,16,18]$ who report that in premature deliveries the CS levels in maternal and umbilical blood are lower than at term. Nevertheless it appears that also in these cases the fetal adrenal gland reacts to fetal acidosis by sccreting more steroids.

\section{Summary}

Does intrautcrine acidosis induce increased steroid secretion? The concentration of free steroids (CS) increases in both fetal and maternal plasma during labor and delivery. Fetal levels are higher after vaginal than after cesarean section. These differences may indicate an important role of the fetal adrenal gland in the induction of labor or they may reflext merely the fetal response to the stress of delivery. During incrased intrauterine stress steroid secretion is increased as shown here.

We examined 41 mothers and their infants during pathological labor. Pathology was assessed from fetal acidosis and/or a clinically obstetric disease of the mother or fetus. The 41 cases included 9 cesarean sections, 8 forceps deliveries; 24 spontaneous deliveries of which 7 were premature. At the time of delivery the $\mathrm{pH}$ and $\mathrm{CS}$ level were determined in maternal and umbilical vessels in all cases.

During spontaneous labor blood samples were also taken during the different stages of labour.

A competetive protein binding assay with transcortin without fractionation of the steroids was used. Progestcron was determined by the same assay. The level of this hormone, however, remains unchanged and hence any changes reflect changes in CS. The levels of CS were correlated with the $\mathrm{pH}$ values and compared to previously obtained normal values.

During pathological delivcries CS levels in hoth mother and fetus are normal as long as there is no acidosis (Fig. 1). If acidosis is present the CS level in the umbilical artery is usually higher than normal. In 13 out of 18 vaginal dcliveries the CS level was above normal, in the other 5 at the upper limit of normal (Fig. 1 and 2). At the same time the $a-v$ difference becomes smaller and sometimes even 
negative. No changes were noted in maternal and umbilical venous blood (Tab. I and II). Similar dependence on the $\mathrm{pH}$ was found for cesarean sections (Tab. III). In premature deliveries without acidosis in the umbilical artery the CS levels were lower in both mother and fetus (Tab. I).
These results indicate that the fetal adrenal gland reacts to acidosis, i. e., intrauterine stress, with increased corticosteroid secretion. This rise depends on the pH of fetal blood and not on the type of delivery (Fig. 3).

Keywords: Acidosis, cesarean section, fetal adrenal gland, forceps, free corticosteroids, vaginal spontaneous delivery.

\section{Zusammenfassung}

Die Konzentration freier Kortikosteroide im fetalen und mütterlichen Plasma bei pathologischen Geburten

Reagiert der Fet bei einer intrauterinen Azidose mit einer gesteigerten Steroidsekretion? Die Konzentration freier Kortikosteroide nimmt während des Geburtsvorganges im mütterlichen und fetalen Plasma zu. Die fetalen Steroidkonzentrationen sind nach vaginalen Entbindungen höher als nach primärer Sectio caesarea. Diese Unterschiede könnten einerseits darauf hinweisen, daß die humane fetale Nebenniere eine wichtige Rolle bei der Geburtsauslösung spielt. Sie könnten jedoch anderseits lediglich der Ausdruck einer fetalen Antwort auf den Geburtsstreß sein. Bei einer verstärkten intrauterinen Streßsituation, nachgeweisen durch eine Azidose, müßte dann die Steroidkonzentration stärker ansteigen. Die Arbeit versucht die letztere Alternative zu beantworten. Untersucht wurden 41 Mütter und deren Kinder während pathologischer Geburten. Die Pathologie äußerte sich im Auftreten einer fetalen Azidose und/oder im Vorliegen einer klinisch-geburtshilflichen Erkrankung der Mutter oder des Feten. Die 41 Fälle unterteilen sich in 9 Sectio caesarea, 8 Forzepsentbindungen und 24 Spontangeburten, davon 7 Frühgeburten. Bei allen Fällen konnte zum Zeitpunkt der Geburt bei der Mutter und in den Nabelgefäßen der aktuelle pH-Wert und die Konzentration freier Kortikosteroide gemessen werden, bei den vaginalen Entbindungen teilweise auch während der Eröffnungs- und Austreibungsperiode.

Als Bestimmungsmethode diente eine Competitive protein binding assay mit Transkortin ohne Steroidfraktionierung. Dabei wurde Progesteron miterfaßt. Da dessen Konzentration unter der Geburt jedoch nicht zunimmt, bedeutet ein Anstieg der Meßwerte eine Zunahme der Kortikosteroide. Im mütterlichen und fetalen Plasma liegen gänzlich verschiedenen Konzentrationsverhältnisse der einzelnen Kortikosteroide vor. $\mathrm{Da}$ die Bestimmung ein- zelner Kortikosteroide die Beantwortung der Fragestellung erschweren würde, verzichteten wir auf eine Steroidfraktionierung. Die gemessenen Konzentrationen der transkortin-affinen Steroidhormone wurden in Beziehung gesetzt zum aktuellen $\mathrm{pH}$-Wert und verglichen mit dem in einer früheren Arbeit mitgeteilten Normalbereich.

Die Veränderungen der Kortikosteroidkonzentration unterscheiden sich bei pathologischen Geburten weder bei der Mutter noch beim Feten von denen beim normalen Geburtsablauf, sofern eine fetale Azidose fehlte (Abb. 1). Bei Auftreten einer Azidose überschreitet jedoch die CSKonzentration der Nabelarterie in der Regel den Normalbereich. Bei 18 vaginalen Entbindungen, einschließlich der Forzepsgeburten, bei denen in der Nabelarterie ein $\mathrm{pH}$-Wert unter 7,20 festgestellt wurde, lag die Kortikosteroidkonzentration in 13 Fällen oberhalb der Norm, in den restlichen 5 Fällen im obersten Normalbereich (Abb. 1 und 2). Gleichzeitig verminderten sich die arteriovenösen Differenzen, die bei einigen Fällen sogar negativ wurden. Die Werte im Nabelvenen- und im mütterlichen Plasma waren gegenüber Normalfällen nur geringgradig erhöht, überstiegen jedoch den Normbereich nicht (Tab. I und II).

Die gleichen Veränderungen konnten bei den Sectiocaesarea-Fällen festgestellt werden, je nachdem ob eine Azidose in der Nabelarterie gemessen werden konnte oder nicht (Tab. III). Bei Frühgeburten, die vaginal entbunden wurden und bei denen keine fetale Azidose vorlag, finden sich durchschnittlich tiefere CS-Konzentrationen bei Mutter und Fetus (Tab. I).

Diese Ergebnisse erlauben die Feststellung, daß die fetale Nebenniere bei Auftreten einer Azidose - im Sinne einer intrauterinen Streßsituation - mit einer vermehrten Ausschüttung von Kortikosteroiden reagiert. Der Konzentrationsanstieg ist dabei abhängig vom fetalen $\mathrm{pH}$-Wert, nicht jedoch von der Art der Geburtsbeendigung (Abb. 3).

Schlüsselwörter: Azidose, fetale Nebenniere, Forzeps, freie Kortikosteroide, Sectio caesarea, vaginale Spontangeburten.

\section{Résumé}

Concentration de corticosteroides libres dans le plasma foetal et maternel en cas d'accouchement pathologique En cas d'acidose intra-utérine, le foetus réagit-il par un accroissement de la sécrétion de stéroides? La concentration de corticostéroides libres augmente dans le plasma foetal et maternel pendant l'accouchement. Les concentrations de stéroides foetales sont plus élevées après accouchement vaginal qu'à la suite d'une section césarienne primaire. Ces différences pourraient donner à supposer, d'une part, que la glande surrénale du foetus humain joue un rôle important dans le déclenchement de l'accouchement, mais il est possible, par ailleurs, qu'elles soient uniquement le résultat d'une réaction foetale au travail de l'accouchement. En cas donc d'un stress intra-utérin particulièrement fort, avec, pour conséquence, une acidose, on devrait pouvoir observer une hausse de la concentration de stéroides. C'est à cette dernière alternative que le présent article tente d'apporter une reponse. 
L'cxamen a porté sur 41 mères et leurs enfants en cours d'accouchement pathologique. Le caractère pathologique de ces accouchements se manifesta par l'apparition d'une acidose foetale et/ou la présence d'une maladic clinicogynécologique de la mère ou du foctus. Ces 41 cas se sont répartis cn 9 sections césariennes, 8 accouchements avec forceps et 24 accouchements spontanés dont 7 prématurés. Dans tous les cas il a été possible de mesurer la valeur actuelle du $\mathrm{pH}$ et la concentration de corticostéroides libres chez la mère et dans les vaisseaux ombilicaux au moment de la naissance et même aussi particllement, pour les accouchements vaginaux, durant la période d'ouverture et d'explusion.

La méthode d'estimation utilisée a été un competitive protein binding assay avec transcortine sans fractionnement de stéroides. La progestérone a été également enregistrée et sa concentration n'augmentant pas pendant l'accouchement, la hausse des valeurs de mesure témoigne donc d'un accroissement des corticostéroides. On observe dans le plasma maternel et le plasma foetal des rapports den concentration des divers corticostéroides entièrement différents. Et comme l'estimation des divers corticostéroides rendrait la solution du problème plus difficile, nous avons renoncé à fractionner les stéroides. Les concentrations mesurées des hormones stéroides ayant une affinité avec la transcortine ont été rapportées à la valeur actuelle du $\mathrm{pH}$ et comparées aux normes établies dans une étude antérieure.

Dans les accouchements pathologiques, les changements de concentration de corticostéroides ne se différencient ni chez la mère ni chez le foetus de celles des acouchements normaux à condition d'absence d'acidose foetale (Fig. 1). En cas d'acidose par contre, la concentration des corticostéroides de l'artère ombilicale dépasse en général la norme. Dans 18 accouchements vaginaux, y compris ceux avec forceps, où on a enregistré dans l'artère mobilicale une valeur de $\mathrm{pH}$ inférieure à 7,20 , la concentration de corticostéroides dépassa la norme dans 13 cas, et se situa, dans les 5 autres cas, au niveau supérieur de la norme (Fig. 1 et 2). En même temps on releva une réduction des différences artério-veineuses qui ont même été négatives dans quelques cas. Les valeurs enregistrées dans le plasma maternel et dans la veine ombilicale dépassèrent de peu seulement celles des cas normaux sans déborder toutefois le niveau normal (Tab. I et II).

Les mêmes changements ont pu être observés dans les cas de section césarienne que l'on ait ou non enregistré de l'acidose dans l'artère ombilicale (Tab. III).

Dans les accouchements prématurés vaginaux et avec absence d'acidose foetale, on a relevé des concentrations de corticostéroides en moyenne plus basses chez la mère comme chez le foetus (Tab. I).

Ces résultats permettent de conclure que la glande surrénale foetale réagit en cas d'acidose - dans le sens d'un stress intrautérin - par une augmentation de la sécrétion de corticostéroides -. La hausse de concentration dépend ici de la valeur de $\mathrm{pH}$ du foetus mais non du processus terminal de l'accouchement (Fig. 3).

Mots-clés: Accouchements spontanés vaginaux, acidose, corticostéroides libres, forceps, glande surrénale foetale, section césarienne.

Acknowledgment: This work was supported by grants from the Schweizerischen Nationalfonds zur Förderung der wissenschaftlichen Forschung, Nr. 3662.

\section{Bibliography}

[1] Alexander, D. P., M. L. Forsling, M. J. Martin, D. A. Nixon, J. G. Ratcliffe, R. Redstone, D. TunBRIDGE: The effect of maternal hypoxia on fetal pituitary hormon release in sheep. Biol. Neonate 21 (1972) 219

[2] Basset, J. M., G. D. Thorburn: Foetal plasma corticosteroids and the initiation of parturition in sheep. J. Endocrin. 44 (1969) 285

[3] Cawson, M. J., A. B. M. Anderson, A. C. TurnBULl, L. LAMPE: Cortisol, cortisone, and 11-Deoxycortisol levels in human umbilical and maternal plasma in relation to the onset of labour. J. Obstet. Gynaec. Brit. Cwlth. 10 (1974) 737

[4] Fylling, P.: Premature parturition following dexamethasone administration to pregnant ewes. Acta endocrin. 66 (1971) 289

[5] Gemzell, C. A.: Variations in plasma levels of $17-$ hydroxycorticosteroids in mother and infant following parturition. Acta endocrin. 17 (1954) 100
[6] Homoki, J., W. M. Teller, D. Tschürtz, A. T. A. FAzEKAS: The concentrations of total cortisol and corticosterone in mixed cord plasma. Acta paediatr. Scand. 64 (1975) 587

[7] Keller, P. J., J. Schmid, M. Ruppen, U. BaertSCHr: Die Plazentafunktion bei Geburtseinleitung mit Prostaglandin $F_{2} \alpha$ und $E_{2}$. In: Prostaglandine in Geburtshilfe und Gynäkologie. Upjohn, Heppenheim 1974

[8] Krauer, F.: Maternal and umbilical cord plasmacortisol-concentrations related to different types of deliveries. Arch. Gynäkol. 215 (1973) 343

[9] Liggrns, G. C.: Premature parturition after infusion of corticotrophin or cortisol into foetal lambs. J. Endocrin. 42 (1968) 323

[10] Mrgeon, C. J., H. Prystowsky, M. M. Grumbach, M. C. Byron: Placental passage of 17-OH-corticosteroids: Comparison of the levels in maternal and 
fetal plasma and effect of ACTH and Hydrocortisone administration. J. clin. Invest. 35 (1956) 488

[11] Mukherjee, K., G. I. M. Swyer: Plasma cortisol and adrenocorticotrophic hormon in normal men and nonpregnant women, normal pregnant women and women with preeclampsia. J. Obstet. Gynaec. Brit. Cwlth. 79 (1972) 678

[12] Murphy, B. E. P.: Some studies of the proteinbinding of steroids and their application to the routine micro and ultramicro measurements of various steroids in body fluids by competitive proteinbinding radioassay. J. clin. Endocrin. 27 (1967) 973

[13] Murphy, B. E. P., R. C. Diez D'Aux: Steroid levels in the human fetus: Cortisol and cortisone. J. clin. Endocrinol. Metab. 35 (1972) 678

[14] Murphy, B. E. P.: Does the human fetal adrenal play a role in parturition? Amer. J. Obstet. Gynec. 115 (1973) 521

[15] Okada, D. M., D. Tulchinsky, J. W. Ross, C. J. Hobel: Plasma estrone, estradiol, estriol, progesterone, and cortisol in normal labor. Amer. J. Obstet. Gynec. 119 (1974) 502
[16] Pokoly, T. B.: The role of cortisol in human parturition. Amer. J. Obstet. Gynec. 15 (1973) 549

[17] SCHMID, J., U. BRINER:! Maternal and fetal levels of free corticosteroids during normal delivery. J. Perinat. Med 3 (1975) 161

[18] Smith, I. D., R. P. Shearman: Fetal plasma steroids in relation to parturition. I The effect of gestationeal age upon umbilical plasma corticosteroid levels following vaginal delivery. J. Obstet. Gynaec. Brit. Cwlth. 81 (1974) 11

[19] Smith, I. D., R. P. Shearman: Fetal plasma steroids in relation to parurition. II. The effect of gestational age upon umbilical plasma corticosteroids following hysterotomy and caesarean section. J. Obstet. Gynaec. Brit. Cwlth. 81 (1974) 16

[20] Talbert, L. M., W. E. Easterling, H. D. Potter: Maternal and fetal plasma levels of adrenal corticoids in spontaneous vaginal delivery and cesarean section. Amer. J. Obstet. Gynec. 117 (1973) 554

[21] Teller, W.: Nebennierenrindenhormone und ihre Veränderungen in der Neugeborenenzeit. In: JopPICH, G., H. Wolf, Metabolism of the newborn. Hippokrates, Stuttgart 1970

Privatdozent Dr. J. Schmid Frauenklinikstraße 22 Universitätsfrauenklinik CH-8091 Zürich 